\title{
Originals
}

\section{In vivo use of neutral radiolabelled molecular probes to evaluate blood-ocular barrier integrity in normal and streptozotocin-diabetic rats}

\author{
J.DiMattio \\ Department of Physiology and Biophysics, New York University School of Medicine, and New York Veterans Administration Hospital,
} New York, USA

\begin{abstract}
Summary. Evidence suggests that the consequences of diabetes mellitus are numerous and that net changes in ocular barrier permeability are necessarily complex functions of changes at specific anatomical loci. In this study we explore changes in blood-aqueous and vitreous permeability in streptozotocin-diabetic rats using five stable radiolabelled probes. Three probes, $\left({ }^{3} \mathrm{H}\right)$-L-glucose, $\left({ }^{14} \mathrm{C}\right)$-sucrose and $\left({ }^{14} \mathrm{C}\right)$-carboxylinulin are relatively large molecules and are expected to move into ocular humours via paracellular routes. Two probes, $\left({ }^{14} \mathrm{C}\right)$-urea and $\left({ }^{14} \mathrm{C}\right)$-glycerol, are small and likely have a trans-cellular component to permeability. Pulse-chase kinetic studies follow the appearance of test molecules into ocular humours with rate constants estimated via linear modelling. Larger neutral probes L-glucose, sucrose and carboxylinulin entered the aqueous humour of control rats slowly via routes that presumably circumvent tight-junctioned barriers. These slow-entry rates were found to increase in diabetic animals suggesting an increase in passive paracellu-
\end{abstract}

lar permeability with significant variation among animals. In contrast, aqueous entry rates of smaller probes urea and glycerol were decreased in diabetic animals suggesting that these probes cross membranes and cells less efficiently in diabetic animals. The magnitude of these changes increased with the length of exposure to diabetes. Paralleling the aqueous humour studies, we found a significant but variable increase in vitreous entry rate with L-glucose, sucrose and carboxylinulin, but a decrease in entry rates with small probes urea and glycerol. These results suggests that diabetes-related blood-ocular permeability changes are complex and depend on the size and properties of the probe as well as the degree of diabetes exposure.

Key words: Diabetes mellitus, blood-aqueous barrier, bloodvitreous barrier, L-glucose, sucrose, carboxylinulin, urea, glycerol, aqueous humour, vitreous humour.
Vascular dysfunction associated with diabetes mellitus in humans and animals is manifested by increased vascular permeability, impaired autoregulation of blood flow, and increased glomerular filtration rate [1-5]. Access to intraocular tissues is limited by a blood-aqueous barrier (BAB) formed by tight junctions of ciliary epithelium and iridial blood vessels with limited movement directly from vessels of the ciliary body [6]. Tight junctions of retinal blood vessels as well as an intact retinal pigment epithelium form a blood-vitreous barrier (BVB) limiting passive permeation into retina and vitreous humour. Fluorescein angiography and fluorophotometry has been used to evaluate net diabetes-related alterations in ocular barriers and as a potential means of determining a level of damage or ocular involvement, however, no clear consensus on early barrier permeability changes in either rats or humans has come forth [7-16].

Evidence suggests that the consequences of diabetes are numerous and varied and that any net change in ocu- lar barrier permeability is necessarily a complex function of individual changes at anatomical loci [5]. Thus, diabetes-related net alterations in passive movement from blood into aqueous humour, for example, could result from changes in vessels supplying the ciliary body and/or in the structure and function of the ciliary epithelia. Recent studies have linked elevated glucose levels to decreased levels of myo-inositol [17-21] and elevated NADH/NAD + ratio via elevated levels of sorbitol and fructose. This is thought to lead to increased protein kinase $\mathrm{C}$ and decreased $\mathrm{Na}^{+}-\mathrm{K}^{+}$-ATPase activity. In turn, these metabolic changes could result in the ability of impaired epithelial cells to maintain transport functions, intercellular junctions and membrane composition - all factors influencing net barrier permeability. Further complicating matters are the processes which occur to perhaps lessen the effects of these metabolic changes including neovascularization and thickening of basement membrane. Current efforts with fluorescein and related 
probes seek to monitor gross paracellular or vascular changes that become apparent during the diabetic process. As such these methods have been most often used to confirm the presence of vascular dysfunction and gross leakage into vitreous associated with diabetic retinopathy. Unfortunately, processes such as vascular occlusion and alterations in cellular and basement membrane, occurring simultaneously with leakage from damaged blood vessels, may result in limiting passive movement of larger probes and minimizing net permeability changes. This would make it difficult to use net permeability increases as a measure of damage caused by the diabetic processes until damage is severe. We reasoned that smaller probes using trans-membrane or trans-cellular routes could provide additional data on the state of structural elements which are unavailable to larger paracellular probes. Additional information concerning the trans-cellular state of blood-ocular barriers might better signal changes occurring earlier in the diabetic process.

In this study, we explore changes in blood-aqueous and vitreous permeability using rats made diabetic with streptozotocin (STZ) and subjected to varying periods of exposure to hyperglycaemia and hypoinsulinaemia using five stable radiolabelled probes. Three probes, $(3 \mathrm{H})$-L-glucose $\left(\mathrm{M}_{\mathrm{r}}-180\right),(14 \mathrm{C})$-sucrose $\left(\mathrm{M}_{\mathrm{r}}-342\right)$ and (14C)-carboxylinulin $\left(\mathrm{M}_{\mathrm{r}}-5000\right)$ are relatively large molecules and can be expected to move into ocular humours primarily via paracellular routes. Two probes, $(14 \mathrm{C})$-urea $\left(\mathrm{M}_{\mathrm{r}}-60.1\right)$ and (14C)-glycerol $\left(\mathrm{M}_{\mathrm{r}}-92.1\right)$ are small and likely have a transcellular component to passive permeability. This is especially true of glycerol which is small and demonstrates the highest octanol/water partition coefficient [22].

\section{Materials and methods}

Transport methods essentially follow those previously published [23-25]. All experiments were performed in male, albino Sprague Dawley rats (275-325 g; 55-72 days old) anaesthetised with sodium pentobarbital (Nembutal, $40 \mathrm{mg} / \mathrm{kg}$, i.p.) using methods conforming to the ARVO (The Association for Research in Vision and Ophthalmology) Resolution on the use of Animals in Research.

Animals were rendered diabetic with STZ dissolved in citric acid $(\mathrm{pH}=4.0)$ via procedures previously reported [26]. STZ $(65 \mathrm{mg} / \mathrm{kg})$ was administered via a tail vein. Plasma glucose was elevated within $24 \mathrm{~h}$ and remained elevated, as monitored via urine and plasma glucose.

D-glucose in urine was monitored periodically with Keto-Diastix reagent strips (Miles Laboratories; Elkart, Ind., USA). D-glucose levels in humours and plasma were determined using a D-glucose specific diagnostic kit supplied by Sigma Chemical Co. (St. Louis, Mo., USA) which is reliable and utilizes the coupled reactions catalysed by hexokinase and glucose 6-phosphate dehydrogenase [27] and read at $340 \mathrm{~nm}$ using a Beckman DU spectrophotometer (Fullerton, Calif., USA). Radiolabelled (3H)-L-glucose (Specific Activity: $20 \mathrm{Cl} / \mathrm{mmol}$ ) was supplied by New England Nuclear, (Boston, Mass., USA). Other radiolabelled probes were supplied by Amersham Corp., (Arlington Heights, III., USA).

In each test animal, the femoral vein was cannulated with polyethylene 50 tubing and connected to a three-way valve on a custom-designed lucite apparatus which allowed for small samples $(50-$ $100 \mu \mathrm{l}$ ) of blood to be withdrawn at will into microcentrifuge collecting tubes.

\section{Transport experiment}

At time zero $(t=0)$, a double labelled bolus of radiolabelled test substances was introduced into the circulation via a cannulated femoral vein using $0.5 \mathrm{ml}$ of saline $(0.9 \% \mathrm{NaCl})$ as the medium. Radiolabelled $\left({ }^{3} \mathrm{H}\right)-\mathrm{L}$-glucose (specific activity: $20.0 \mathrm{Ci} / \mathrm{mmol}$ ) was supplied by New England Nuclear, $\left({ }^{14} \mathrm{C}\right)$-Carboxylinulin (specific activity: $5.1 \mathrm{mCi} / \mathrm{mmol}$ ); $\left({ }^{14} \mathrm{C}\right.$ )-glycerol (specific activity: $171 \mathrm{mCi} / \mathrm{mmol}$ ); $\left({ }^{14} \mathrm{C}\right)$-urea (specific activity: $\left.55 \mathrm{mCi} / \mathrm{mmol}\right) ;\left({ }^{14} \mathrm{C}\right)$ sucrose (specific activity: $3.6 \mathrm{mCi} / \mathrm{mmol}$ ) were supplied by Amersham Corp. The specific activity of test molecules did not vary significantly during the short 13-min experimental period since the concentrations of unlabelled test molecules remained stable. $5 \mu \mathrm{Ci}$ of test radiolabel along with $5 \mu \mathrm{Ci}\left({ }^{3} \mathrm{H}\right)$-L-glucose was used for each dual label experiment. From $t=0$ to $t=\mathrm{T}$, blood samples were removed from the circulation at 1,2,3,5,7,9,11 and 13 min in the 13-min transport experiments. In longer term experiments samples were taken at 3-5 min intervals.

At time $t=\mathrm{T}$, the animal was killed with an i.v. overdose of pentobarbital. The eyes were quickly enucleated and samples of aqueous and vitreous humours were taken within $2-5$ min post mortem. Vitreous humour $(10-20 \mu \mathrm{l})$ was taken first by cutting off the optic stub, allowing vitreous humour to pool in a clean glass collecting dish. Residual vitreous was blotted away and aqueous humour (10-20 $\mu$ l) obtained through a cut into the corneoscleral limbus using calibrated glass constriction pipettes.

Calibrated aliquots of plasma and samples of aqueous, vitreous and cerebrospinal fluid were counted via liquid scintillation spectrometry (Beckman LS 7500) using Liquiscint (National Diagnostics, Somerville, NJ, USA) as the scintillation cocktail. Appropriate corrections for channel spillover and quenching were made with computer assistance to obtain DPM/ml counts for each labelled test substance.

\section{Rate constant determination}

The plasma isotopic concentration data $C_{p}(t)$ vs time, for each radiolabelled test molecule was fit graphically to a double exponential decay curve of the form:

$\mathrm{C}_{\mathrm{P}}=\mathrm{A}+\mathrm{Be}^{-\mathrm{b} 1 \mathrm{t}}+\mathrm{Ce}^{-\mathrm{b} 2 \mathrm{t}}$

where $A, B, C, b_{1}, b_{2}$ are determined constants and $A$ has been shown to be the plasma concentration at $t=\infty, \mathrm{C}_{\mathrm{p}}(\infty)$. The graphically determined constants were used as first guess approximations for a "best fit" determination of the same constants via curve fitting the above data using Asystant software (Macmillan Software Co., NY, USA). The data analysis software provided "goodness of fit parameters", one of which was a multiple correlation coefficient. The graphical analysis previously used by us generally resulted in a correlation coefficient, $\mathrm{R}^{2}$, of better than 0.98 , whereas Asystant allowed us to improve our estimates to $\mathrm{R}^{2}$ of 0.992 or better.

For transport from blood plasma to aqueous humour, a simplified linear first order system equation was used:

$\mathrm{dC}_{\mathrm{A}} / \mathrm{dt}=\mathrm{K}_{\mathrm{Ai}} \mathrm{CP}_{\mathrm{P}}-\mathrm{K}_{\mathrm{Ao}} \mathrm{C}_{\mathrm{A}}$.

Eq. 2.

This equation indicates that the rate of change of concentration in aqueous humour is dependent simply on linear entry and exit rates with defined rate constants, $\mathrm{K}_{\mathrm{Ai}}$ and $\mathrm{K}_{\mathrm{Ao}}$. Note, at $t=\infty$,

$\mathrm{K}_{\mathrm{Ai}} / \mathrm{K}_{\mathrm{Ao}}=\mathrm{C}_{\mathrm{A}} / \mathrm{C}_{\mathrm{P}}(\infty)$

Eq. 3.

In our modelling three possibilities are considered. For simple diffision and carrier facilitated diffusion, the two adjacent compartments (eg. plasma-aqueous) eventually come to a transport steady-state with concentrations nearly equal and thus,

$\mathrm{C}_{\mathrm{A}} / \mathrm{C}_{\mathrm{P}}(\infty)=1.0$ and

$\mathrm{K}_{\mathrm{Ai}}=\mathrm{K}_{\mathrm{Ao}}=\mathrm{K}_{\mathrm{A}}$

Eq. 4. 


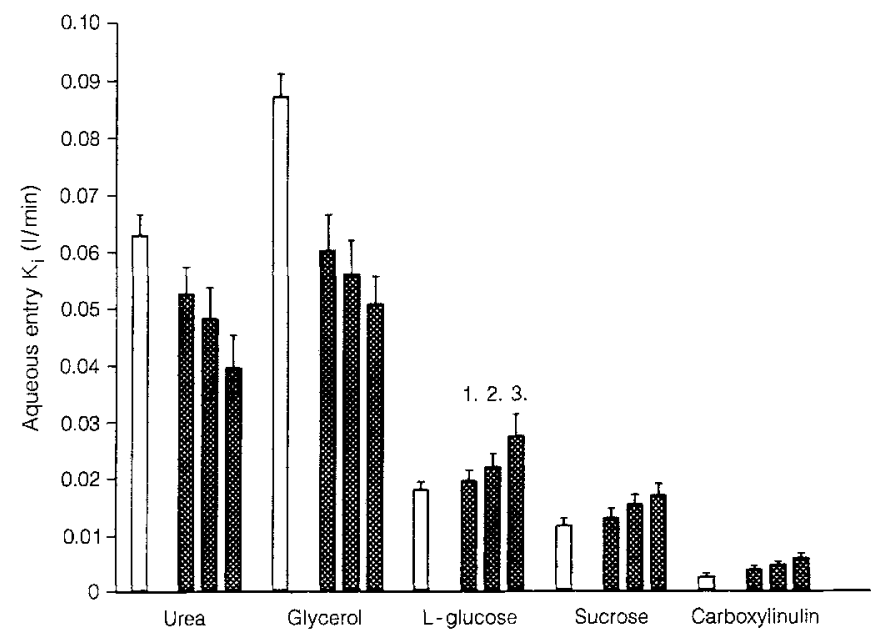

Fig.1. Results of blood-aqueous entry rate constants calculated from 13-min pulse-chase experiments in normal rats $(\square)$ and compared with results from streptozotocin diabetic rats ( ) for the various probes listed. Streptozotocin-diabetic animals are categorized according to exposure as short-term (1), mid-term (2) and long-term (3) diabetes. Bars consist of means \pm SDM

Another possibility is that $\mathrm{C}_{\mathrm{A}} / \mathrm{C}_{\mathrm{P}}(\infty)>1.0$ suggesting that some mechanism such as an active transport carrier is present which allows the aqueous compartment to accumulate label to concentrations higher than those from which they originated. This assumes that the labelled test molecule being studied is accumulated by an energy requiring process. A third possibility is when the steady-state value approaches some value less than one asymptotically. This is the most difficult case in that it could arise from an over-estimation of the volume of distribution (some part of the estimated water compartment may not be available to the labelled test molecule) or it could be the result of the exit rate from that compartment being greater than the entry rate leading to a steady-state less than zero. In very slow processes it is difficult to distinguish which is the appropriate analysis. We note, however, as long as rate constant estimates are made from data sufficiently removed from steady-state some fair estimate of an entry constant is still possible. We did not encounter active transport with any of the five test molecules used in this work and limit our analysis to simple or facilitated diffusion. Using L-glucose as a control or passive marker allowed us to compare results with the other test molecules at least on some relative basis.

\section{Aqueous humour concentration}

As reported previously $[23,25]$, the aqueous humour concentration vs time appearance function derived from equations 1 , and 2 was shown to be of the form:

$C_{A}(t)=S_{1}\left[A_{A 1}+A_{A 2} e^{-K A o t}+A_{A 3} e^{-b 1 t}+A_{A 4} e^{-b 2 t}\right]$

Eq. 5 .

where

$\mathrm{S}_{1}=\frac{\mathrm{C}_{\mathrm{A}}(\infty)}{\mathrm{C}_{\mathrm{P}}(\infty)}=\frac{\mathrm{K}_{\mathrm{Ai}}}{\mathrm{K}_{\mathrm{Ao}}}$

Eq. 6.

and

$A_{A 1}=C_{A}(\infty) / S_{1}=C_{P}(\infty)=A$

$\mathrm{A}_{\mathrm{A} 2}=\frac{\mathrm{K}_{\mathrm{Ao}} \mathrm{B}}{\mathrm{b}_{1}-\mathrm{K}_{\mathrm{AO}}}+\frac{\mathrm{K}_{\mathrm{Ao}} \mathrm{C}}{\mathrm{b}_{2}-\mathrm{K}_{\mathrm{Ao}}}-\mathrm{A}$

Eq. 7.

$\mathrm{A}_{\mathrm{A} 3}=\frac{\mathrm{K}_{\mathrm{A0}} \mathrm{B}}{\mathrm{K}_{\mathrm{Ao}}-\mathrm{b}_{1}}$

Eq. 8.

$\mathrm{A}_{\mathrm{A} 4}=\frac{\mathrm{K}_{\mathrm{Ao}} \mathrm{C}}{\mathrm{K}_{\mathrm{Ao}}-\mathrm{b}_{2}}$

Eq. 9.

Eq. 10.

A computer trial and error solution of Eq. 5 to 10 allows for the estimation of transport constants $\mathrm{K}_{\mathrm{Ai}}$ and $\mathrm{K}_{\mathrm{Ao}}$ using the determined plas-
J. DiMattio: Blood-ocular barrier integrity in streptozotocin-diabetic rats

ma curve constants of Eq. 1 and explicit aqueous concentration data at a specific time, $T$, the end of the experiment. Similar modelling was used for determining vitreous rate constants.

\section{Statistical analysis}

Data was collected and means $\pm S D$ are reported. Differences between groups are evaluated using the Student's $t$-test with $p$ value reported.

\section{Results}

Figure 1 illustrates our blood-aqueous results with passive probes $(3 \mathrm{H})$-L-glucose $\left(\mathrm{M}_{\mathrm{r}}-180\right),(14 \mathrm{C})$-sucrose $\left(\mathrm{M}_{\mathrm{r}^{-}}\right.$ $432.3)$ and $(14 \mathrm{C})$-carboxylinulin $\left(\mathrm{M}_{\mathrm{r}}-5000+\right)$ and smaller probes $(14 \mathrm{C})$-urea $\left(\mathrm{M}_{\mathrm{r}}-60.1\right)$ and $(14 \mathrm{C})$-glycerol $\left(\mathrm{M}_{\mathrm{T}}\right.$ 92.11). Short-term pulse chase kinetic studies of 13 14 min duration were used to determine entry rate constants in control and diabetic animals of varying levels of exposure to diabetes.

Diabetic animals showed clear symptoms including weight loss, hyperglycaemia (as monitored by elevated glucose levels in blood and urine; ketone levels also monitored) and low insulin levels. We note that some $20 \%$ of our animals died before reaching 100 days of diabetes. In order to estimate a fair or comparable level of exposure to the diabetes, we considered a low exposure level to be 10 20 days and a high exposure to be 100 days or more. The level of the diabetes, as estimated by plasma and urine glucose levels, was generally comparable from one animal to another (normal: $155 \pm 8 \mathrm{mg}$ glucose $/ 100 \mathrm{ml}$; 30-day diabetic: $434 \pm 78 \mathrm{mg}$ glucose $/ 100 \mathrm{ml}$; 60 -day diabetic; $462 \pm 84 \mathrm{mg}$ glucose $/ 100 \mathrm{ml}$ ) beginning with the second day post STZ administration. Therefore, we use the number of days of relatively uniform hyperglycaemia as an index of level of exposure. Age-matched controls resulted in minor decreases in measured entry constants which would be applicable only to older diabetic rats $(100+$ days $)$. This age-related decrease in measured entry rate (probably related to ocular volume) amounted to less than $10 \%$ and did not account for the differences noted with diabetic animals. Specific activity remained constant throughout the short-term 13-min experiment since the concentrations of the unlabelled test molecules did not vary appreciably from $t=0$ to $t=13 \mathrm{~min}$.

Figure 1 reveals that control entry rate levels of urea and glycerol are significantly higher $(p<0.001)$ than those of larger probes L-glucose, sucrose and carboxylinulin. Test molecules are arranged in order of molecular size with urea being smallest and carboxylinulin, largest. It is glycerol, however, that moves into aqueous humour fastest, probably reflecting its greater lipid solubility than urea [22] and the importance of physical properties in determining trans-cellular movement [28]. Other than the exception noted with glycerol, entry rates followed an inverse relationship with size.

Results with diabetic animals reveal that entry rates decreased with urea and glycerol, but increased with larger probes. As the period of diabetic exposure increased this pattern continued. With the larger probes, not all diabetic 
Table 1. Blood-aqueous entry rate constant, $\mathrm{K}_{\mathrm{Ai}}$, in control and diabetic rats

\begin{tabular}{|c|c|c|c|c|c|}
\hline \multirow{2}{*}{\multicolumn{2}{|c|}{$\begin{array}{c}S_{1} \\
\text { Days post streptozotocin }\end{array}$}} & \multirow[t]{2}{*}{ Control rats } & \multicolumn{3}{|l|}{ Diabetic rats } \\
\hline & & & \multirow{2}{*}{$\begin{array}{l}10-20 \text { days } \\
0.0525 \pm 0.0048 \\
(7) \\
-16.8 \\
<0.005\end{array}$} & \multirow{2}{*}{$\begin{array}{l}40-60 \text { days } \\
0.0483 \pm 0.0058 \\
(7) \\
-23.5 \\
<0.001\end{array}$} & \multirow{2}{*}{$\begin{array}{l}100+\text { days } \\
0.0394 \pm 0.0056^{a} \\
(6) \\
-37.6 \\
<0.001\end{array}$} \\
\hline $\begin{array}{l}\text { Urea } \\
n \\
\% \text { change } \\
p \text {-value }\end{array}$ & 1.0 & $\begin{array}{l}0.0631 \pm 0.0032 \\
(10)\end{array}$ & & & \\
\hline $\begin{array}{l}\text { Glycerol } \\
n \\
\% \text { change } \\
p \text {-value }\end{array}$ & 1.0 & $\begin{array}{l}0.0872 \pm 0.0038 \\
(11)\end{array}$ & $\begin{array}{l}0.0603 \pm 0.0062 \\
(7) \\
-30.9 \\
<0.001\end{array}$ & $\begin{array}{l}0.0562 \pm 0.0056 \\
(7) \\
-35.6 \\
<0.001\end{array}$ & $\begin{array}{l}0.0509 \pm 0.0049 \\
(8) \\
-41.6 \\
<0.001\end{array}$ \\
\hline $\begin{array}{l}\text { L-glucose } \\
n \\
\% \text { change } \\
p \text {-value }\end{array}$ & 1.0 & $\begin{array}{l}0.0181 \pm 0.0012 \\
(14)\end{array}$ & $\begin{array}{l}0.0197 \pm 0.0018 \\
(7) \\
+8.84 \\
\text { NS }\end{array}$ & $\begin{array}{l}0.0221 \pm 0.0024 \\
(8) \\
+22.1 \\
<0.01\end{array}$ & $\begin{array}{l}0.0272 \pm 0.0038 \\
(8) \\
+50.3 \\
<0.001\end{array}$ \\
\hline $\begin{array}{l}\text { Sucrose } \\
n \\
\% \text { change } \\
p \text {-value }\end{array}$ & 0.31 & $\begin{array}{l}0.0118 \pm 0.0011 \\
(9)\end{array}$ & $\begin{array}{l}0.0131 \pm 0.0016 \\
(6) \\
+11.0 \\
\text { NS }\end{array}$ & $\begin{array}{l}0.0155 \pm 0.0017 \\
(8) \\
+31.4 \\
<0.001\end{array}$ & $\begin{array}{l}0.0172 \pm 0.0019 \\
(8) \\
+45.8 \\
<0.001\end{array}$ \\
\hline $\begin{array}{l}\text { Carboxyl- } \\
\text { inulin } \\
\% \text { change } \\
p \text {-value }\end{array}$ & 0.21 & $\begin{array}{l}0.0027 \pm 0.0004 \\
(8)\end{array}$ & $\begin{array}{l}0.0039 \pm 0.0006 \\
(7) \\
+44.4 \\
<0.01\end{array}$ & $\begin{array}{l}0.0047 \pm 0.0006 \\
(8) \\
+74.1 \\
<0.001\end{array}$ & $\begin{array}{l}0.0059 \pm 0.0008 \\
(6) \\
+118.5 \\
<0.001\end{array}$ \\
\hline
\end{tabular}

a Values listed as means \pm SDM with the number of experiments in parentheses below

animals demonstrated increases in the rate of passive movement into aqueous, but 19 of 23 did. Increased entry rates were noted with all three "larger" passive probes which reflect paracellular movement at vascular and epithelial sites. Table 1 illustrates this more clearly since differences between control and diabetic animals become statistically significant only after 40-60 days exposure. Moreover, variation among experiments reflected in the $\mathrm{SD}$, increased with diabetes exposure. Thus, with L-glucose, for example, the SD of $6.6 \%$ in control rats increased to $14.0 \%$ in 100 + days diabetic animals. Clearer differences from control values are seen in early diabetes with smaller probes, especially glycerol.

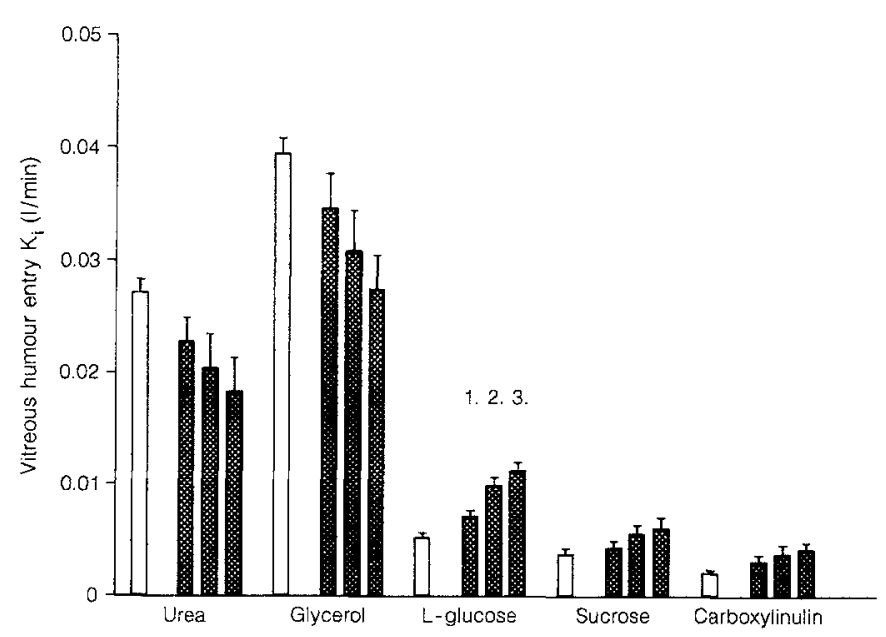

Fig. 2. Results of blood-vitreous entry rate constants calculated from 13-min pulse-chase experiments in normal rats $(\square)$ and compared with results from streptozotocin diabetic rats ( ) for the various probes listed. Streptozotocin-diabetic animals are categorized according to exposure as short-term (1), mid-term (2) and long-term (3) diabetes. Bars consist of means \pm SDM
A similar pattern of results are observed in Figure 2 which illustrates entry rate constants of movement across the blood-vitreous barrier with the same radiolabelled passive probes $(3 \mathrm{H})$ - $\mathrm{L}$-glucose, $(14 \mathrm{C})$-sucrose and $(14 \mathrm{C})$ carboxylinulin and smaller probes (14C)-urea and (14C)glycerol. Table 2 reveals that percent increases in entry rate constants with probes (3H)-L-glucose and (14C)-sucrose are greater across the blood-vitreous than bloodaqueous barriers. In addition, decreases seen in diabetic animals with urea and glycerol are more modest across the blood-vitreous than across the blood-aqueous barriers.

\section{Discussion}

Results of control studies indicate that plasma-aqueous entry constants for L-glucose, sucrose, and carboxylinulin correlate well with size. Passive marker carboxylinulin is the largest labelled probe used and moved into aqueous humour slowest. Of the 31 diabetic animals used with these probes 26 had entry constants above the $95 \%$ confidence limits and none below. Five animals demonstrated constants within the $95 \%$ confidence limits although they exhibited signs of a similar exposure to diabetes (elevated blood and urine glucose levels). A similar situation was observed with diabetic animals across the blood-aqueous barriers. Thus, net changes in diabetic animals are not clearly consistent. Although the larger molecules clearly enter the aqueous at slower rates than urea or glycerol, they are not completely kept out of aqueous even in normal animals. An impenetrable and fully tight-junctioned blood-aqueous barrier would be expected to exhibit a much slower carboxylinulin entry rate as it is some 30 times larger than L-glucose. This gives support to recent studies by Fredda et al. [6] with rabbits which suggest that proteins enter the anterior aqueous directly from the ciliary stroma by diffusion to the anterior iris surface. In 
Table 2. Blood-vitreous entry rate constant, $\mathrm{K}_{\mathrm{Vi}}$, in control and diabetic rats

\begin{tabular}{|c|c|c|c|c|c|}
\hline \multirow{2}{*}{\multicolumn{2}{|c|}{$\begin{array}{c}\mathrm{S}_{1} \\
\text { Days post streptozotocin }\end{array}$}} & \multirow[t]{2}{*}{ Control } & \multicolumn{3}{|l|}{ Diabetic } \\
\hline & & & \multirow{2}{*}{$\begin{array}{l}10-20 \text { days } \\
0.0228 \pm 0.0020 \\
(7) \\
-15.9 \\
<0.002\end{array}$} & \multirow{2}{*}{$\begin{array}{l}40-60 \text { days } \\
0.0204 \pm 0.0031 \\
(7) \\
-24.7 \\
<0.001\end{array}$} & \multirow{2}{*}{$\begin{array}{l}100+\text { days } \\
0.0183 \pm 0.0030^{\mathrm{a}} \\
(6) \\
-32.5 \\
<0.001\end{array}$} \\
\hline $\begin{array}{l}\text { Urea } \\
n \\
\% \text { change } \\
p \text {-value }\end{array}$ & 1.0 & $\begin{array}{l}0.0271 \pm 0.0012 \\
(10)\end{array}$ & & & \\
\hline $\begin{array}{l}\text { Glycerol } \\
n \\
\% \text { change } \\
p \text {-value }\end{array}$ & 1.0 & $\begin{array}{l}0.0394 \pm 0.0014 \\
(11)\end{array}$ & $\begin{array}{l}0.0346 \pm 0.0031 \\
(7) \\
-12.2 \\
<0.01\end{array}$ & $\begin{array}{l}0.0309 \pm 0.0034 \\
(7) \\
-21.6 \\
<0.001\end{array}$ & $\begin{array}{l}0.0275 \pm 0.0030 \\
(8) \\
-30.2 \\
<0.001\end{array}$ \\
\hline $\begin{array}{l}\text { L-glucose } \\
n \\
\% \text { change } \\
p \text {-value }\end{array}$ & 1.0 & $\begin{array}{l}0.0052 \pm 0.0004 \\
(14)\end{array}$ & $\begin{array}{l}0.0071 \pm 0.0005 \\
(7) \\
+8.84 \\
\text { NS }\end{array}$ & $\begin{array}{l}0.0099 \pm 0.0007 \\
(8) \\
+22.1 \\
<0.01\end{array}$ & $\begin{array}{l}0.0112 \pm 0.0008 \\
(8) \\
+50.3 \\
<0.001\end{array}$ \\
\hline $\begin{array}{l}\text { Sucrose } \\
n \\
\% \text { change } \\
p \text {-value }\end{array}$ & 0.22 & $\begin{array}{l}0.0038 \pm 0.0005 \\
(9)\end{array}$ & $\begin{array}{l}0.0044 \pm 0.0005 \\
(6) \\
+15.8 \\
\mathrm{NS}\end{array}$ & $\begin{array}{l}0.0056 \pm 0.0008 \\
(8) \\
+47.4 \\
<0.002\end{array}$ & $\begin{array}{l}0.0061 \pm 0.0010 \\
(8) \\
+60.5 \\
<0.001\end{array}$ \\
\hline $\begin{array}{l}\text { Carboxyl- } \\
\text { inulin } \\
\% \text { change } \\
p \text {-value }\end{array}$ & 0.16 & $\begin{array}{l}0.0022 \pm 0.0003 \\
(8)\end{array}$ & $\begin{array}{l}0.0032 \pm 0.0006 \\
(7) \\
+45.4 \\
<0.005\end{array}$ & $\begin{array}{l}0.0039 \pm 0.0008 \\
(8) \\
+77.3 \\
<0.001\end{array}$ & $\begin{array}{l}0.0043 \pm 0.0006 \\
(6) \\
+95.4 \\
<0.001\end{array}$ \\
\hline
\end{tabular}

${ }^{a}$ Values listed as means \pm SDM with the number of experiments in parentheses below

addition, vesicular transport could contribute to net movement of all molecular species used in this study including carboxylinulin, but we suggest that it is unlikely that any major contribution could occur in the short 13-14 min of our experiments.

Thus, our data with relatively large passive probes suggest that in most cases there is an increase in passive permeability across the blood-aqueous barriers in the STZdiabetic rats. This increase is significant but variable and could well reflect a net result of complex processes of damage and repair. The blood vitreous data reveals a greater spread of difference in entry constants of large and small probes. The pattern of increased permeability with the larger probes seen across both blood-aqueous and blood-vitreous barriers in the diabetic animals could reflect results of similar processes of damage and repair at these separate and distinct loci.

We note that smaller passive probes, urea and glycerol, cross into the aqueous and vitreous humours fastest [28], but at slower rates in diabetic than control animals. This was unexpected since any general increase in permeability across a simple uniform barrier might be expected to be seen with any passive probe. Consider, however, that blood-ocular barriers are not simple and our observation could be explained by the development of diabetes-related processes that result in an increase in pore size or frequency at some anatomical loci occurring in conjunction with a decrease in some other loci. It could not be explained simply by a decrease in blood delivery to humour secreting tissues since this would also decrease the net movement of larger probes L-glucose, sucrose, and carboxylinulin. It is this difference seen with small and larger passive probes that could prove significant and a fact that could be exploited in attempting to assay barrier damage with probes.

The accompanying Figure 3 illustrates this in schematic form. The number or size of larger pores, (the route used by larger molecules) could increase (even double) at the same time that the number or size of the smaller pores decreases. This is not unlike the complex ultrastructural changes associated with diabetes as described in the diabetes literature. This could include changes in endothelial cells lining capillaries, thickening of basement membrane and structural changes in the retinal pigment epithelium (RPE). These changes could result in increased permeability across the RPE, but decreased per-

\section{Normal rats}

\begin{tabular}{|cccccccccccccccc}
0 & 0 & 0 & 0 & 0 & 0 & 0 & 0 & 0 & 0 & 0 & 0 & 0 & 0 \\
0 & 0 & 0 & 0 & 0 & 0 & 0 & 0 & 0 & 0 & 0 & 0 & 0 & 0 & 0 & 0 \\
0 & 0 & 0 & 0 & 0 & 0 & 0 & 0 & 0 & 0 & 0 & 0 & 0 \\
0 & 0 & 0 & 0 & 0 & 0 & 0 & 0 & 0 & 0 & 0 & 0 & 0 & 0 & 0 \\
0 & 0 & 0 & 0 & 0 & 0 & 0 & 0 & 0 & 0 & 0 & 0 & 0 & 0 \\
0 & 0 & 0 & 0 & 0 & 0 & 0 & 0 & 0 & 0 & 0 & 0 & 0 & 0 & 0 \\
0 & 0 & 0 & 0 & 0 & 0 & 0 & 0 & 0 & 0 & 0 & 0 & 0 & 0 & 0 & 0 \\
0 & 0 & 0 & 0 & 0 & 0 & 0 & 0 & 0 & 0 & 0 & 0 & 0 \\
0 & 0 & 0 & 0 & 0 & 0 & 0 & 0 & 0 & 0 & 0 & 0 & 0 & 0 \\
0 & 0 & 0 & 0 & 0 & 0 & 0 & 0 & 0 & 0 & 0 & 0 & 0 \\
0
\end{tabular}

STZ-diabetic rats

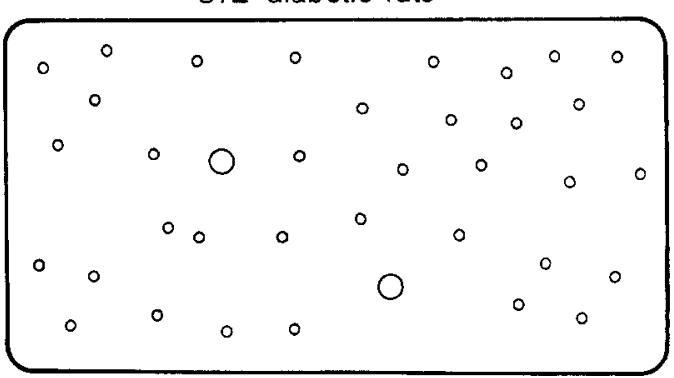

Fig. 3. Model of diabetic changes including an increase in the frequency of larger sized pores corresponding to paracellular damage along with a decrease in frequency of smaller membrane permeability sources 
meability, for example, across the basement membranes. Other consequences of the diabetic process could involve increased permeability across endothelial cells and/or decreased permeability across specific membranes of epithelial cells of the ciliary process or retinal pigment epithelium. The net change in permeability across the blood-vitreous barrier for example, as seen with fluorescein, allows no way of discerning more specific information. Multiple probes of different sizes and physical properties could allow differentiation of transcellular movement from paracellular movement occurring through breaks in microvessels and/or epithelial barriers of diabetic animals. Although no study uses the same pulse-chase techniques as reported in this study, other reports do suggest increases in blood-retinal barrier, as examined with sucrose and other probes $[29,30]$ which could correspond to our blood-vitreous permeability increase. This study, for the first time, uses a range of probes to examine changes in blood-aqueous and -vitreous entry rates in STZ-diabetic rats, which could relate directly to permeability assuming no real changes in transfer area. We suggest that permeability increases can only be detected with larger probes probably moving through larger intercellular breaks (RPE, endothelium) and that smaller probes do no show this permeability increase, perhaps because they move across membranes and barriers that have been changed by the diabetic process and offer a greater resistance to transcellular movement.

Acknowledgements. The author is indebted to Mr. J.Streitman for expert technical assistance. The computer and editorial assistance of Mr. A.Drayton is gratefully acknowledged. In addition, the author wishes to thank Dr. V.Fisher for V.A.Hospital facilities without which this work would not have been possible. This work has been supported by Research Grant EY 04418 from The National Institute of Health (NEI), Bethesda, Md.

\section{References}

1. Mogensen CE (1971) Kidney function and glomerular permeability to macromolecules in early juvenile diabetes. Scand J Clin Lab Invest 28: 79-90

2. Mogensen CE (1972) Glomerular filtration rate and renal plasma flow in long term juvenile diabetics without proteinurea. Br Med J 4:257-259

3. Bloodworth JMB (1980) Pathology of the diabetic kidney. In: Friedman EA, L'Esperance Jr, FA (eds) Diabetic renal-retinal syndrome. Academic Press, London pp 159-174

4. Buzney SM, Weiter JJ (1984) Pathogenesis of diabetic retinal angiography: Proposed mechanisms of current research. In: Pavan PR (ed) Ocular manifestations of diabetes. Little Brown \& Co, Boston pp 1-12

5. Stackhouse S, Miller PL, Park SK, Meyer TW (1990) Reversal of glomerular hyperfiltration and renal hypertrophy by blood glucose normalization in diabetic rats. Diabetes 39: 895-898

6. Fredda TF, Bartels SP, Kamm RD (1990) The source of protein in the aqueous humor of normal rabbit. Invest Ophthalmol Vis Sci 31: $125-137$

7. Novotny HR, Alvis DL (1961) Method of photographing fluorescence in circulating blood in the human retina. Circulation 24 : $82-86$

8. Norton EW, Gutman F (1967) Fluorescein angiography of the retina in diabetes mellitus. In: Kimura S, Caygill W (eds) Vascular complications of diabetes mellitus with special emphasis in microangiopathy of the eye. Mosby, St Louis, pp 120-136
9. Cunha-Vas JG, Maurice DM (1967) The active transport of fluorescein by the retinal vessels and the retina. J Physiol 191:467-486

10. Cunha-Vas JG, de Abreau FJR, Campos AJ, Figo GM (1975) Early breakdown of the blood-retinal barrier in diabetes. $\mathrm{Br} \mathrm{J}$ Ophthalmol 59: 49-65

11. Waltman SE, Oestreich C, Krupin T et al. (1978) Quantitative vitreous fluorophotometry. A sensitive technique for measuring early breakdown of the blood retinal barrier in young diabetic patients. Diabetes 27: 85-87

12. Klein R, Ernest JT, Engerman R (1980) Fluorophotometry: II streptozotocin-treated guinea pigs. Arch Ophthalmol 98: 22332234

13. Jones CW, Cunha-Vas JG, Zweig KO, Stein MA (1979) Kinetic vitreous fluorophotometry in experimental diabetes. Arch Ophthalmol 97: 1941-1947

14. Grimes PA, McGlinn A, Laties AM, Naji A (1984) Increase of basal cell membrane area of the retinal pigment epithelium in experimental diabetes. Exp Eye Res 38: 569-577

15. Blair NP, Rusin MM (1986) Blood-retinal barrier permeability to carboxyfluorescein and fluorescein in monkeys. Graefes. Arch Clin Exp Ophthalmol 224: 419-422

16. Fang T, Naguib KS, Peyman GA, Khoobehi B (1990) Comparative study of three fluorescent dyes for angiography: sodium fluorescein, carboxyfluorescein and calcein. Ophthalmic Surg $21: 250-257$

17. Hammerman MC, Sacktor B, Daughaday WH (1980) Myo-inositol transport in renal brush border vesicles and its inhibition by D-glucose. Am J Physiol 239: 113-120

18. Berridge MJ (1984) Inositol triphosphate and diacylglycerol as second messengers. Biochem J 220: 345-360

19. Biden TJ, Wollheim CB (1986) Active transport of myo-inositol in rat pancreatic islets. Biochem J 236: 889-893

20. Li W, Chan LS, Khatami M, Rockey JH (1986) Non-competitive inhibition of myoinositol transport in cultured bovine retinal capillary pericytes by glucose and reversal by Sorbinil. Biochim Biophys Acta 857: 198-207

21. Khatami M, Rockey JH (1988) Regulation of uptake of inositol by glucose in cultured retinal pigment epithelium cells. Biochem Cell Biol 66: 951-957

22. Rapoport SI (1976) Sites and functions of the blood-aqueous and vitreous barriers of the eye. In: Blood-brain barrier in physiology and medicine. Raven Press, New York, pp 207-233

23. DiMattio J, Zadunaisky JA (1981) Glucose transport into ocular compartments of the rat. Exp Eye Res 32: 517-532

24. DiMattio J (1984) In vivo entry of glucose analogs into lens and cornea of the rat. Invest Ophthalmol Vis Sci 25: 160-165

25. DiMattio J (1989) A comparative study of ascorbic acid entry into aqueous and vitreous humors of the rat and guinea pig. Invest Ophthalmol Vis Sci $30: 36-47$

26. DiMattio J (1984) Onset of changes in glucose transport across ocular barriers in streptozotocin-induced diabetes. Invest Ophthalmol Vis Sci 25: 820-826

27. Washko ME, Rice FW (1981) Determination of glucose by an improved enzymatic procedure. Clin Chem 7: 542-544

28. Ross EJ (1951) The transfer of non-electrolytes across the bloodaqueous barrier. J of Physiol 112: 229-237

29. Lightman S, Pinter G, Yuen L, Bradbury M (1990) Permeability changes at blood retinal barrier in diabetes and the effect of aldose reductase inhibition. Am J Physiol 259: R601-R605

30. Williamson J, Chang K, Tilton R et al. (1987) Increased vascular permeability in spontaneously diabetic $\mathrm{BB} / \mathrm{W}$ rats and in rats with mild versus severe streptozotocin induced diabetes. Diabetes 36: 813-821

Received: 13 May 1991

and in revised form: 2 September 1991

\section{Dr. J. DiMattio}

Department of Physiology and Biophysics

550 First Avenue

New York, NY 10016, USA 